\title{
Calcium pyrophosphate dihydrate crystal deposition disease and retro-odontoid pseudotumor rupture managed via posterior occipital cervical instrumented fusion: illustrative case
}

\author{
Armaan K. Malhotra, MD, ${ }^{1}$ Aayush R. Malhotra, MKin, ${ }^{2}$ Alexander P. Landry, MD, ${ }^{1}$ Arjun Balachandar, MD, ${ }^{3}$ William Guest, MD, PhD, ${ }^{4}$ \\ Aditya Bharatha, MD, ${ }^{4}$ Thomas R. Marotta, MD, ${ }^{4}$ and Christopher D. Witiw, MD, MS ${ }^{1}$

\begin{abstract}
${ }^{1}$ Division of Neurosurgery and ${ }^{4}$ Department of Interventional Neuroradiology, St. Michael's Hospital, University of Toronto, Toronto, Ontario, Canada; ${ }^{2}$ Department of Kinesiology, University of British Columbia, Vancouver, British Columbia, Canada; and ${ }^{3}$ Department of Neurology, University of Toronto, Toronto, Ontario, Canada
\end{abstract}

BACKGROUND Craniocervical junction and subaxial cervical spinal manifestations of calcium pyrophosphate deposition disease are rarely encountered. The authors presented a severe case of retro-odontoid pseudotumor rupture causing rapid quadriparesis and an acute comatose state with subsequent radiographic and clinical improvement after posterior occipital cervical fusion.

OBSERVATIONS The authors surveyed the literature and outlined multiple described operative management strategies for compressive cervical and craniocervical junction calcium pyrophosphate deposition disease manifestations ranging from neck pain to paresthesia, weakness, myelopathy, quadriparesis, and cranial neuropathies. In this report, radiographic features of cervical and craniocervical junction calcium pyrophosphate deposition disease were explored. Several previously described surgical strategies were compiled, including patient characteristics and outcomes.

LESSONS With this case report, the authors presented for the first time an isolated posterior occipital cervical fusion for treatment of a compressive retro-odontoid pseudotumor with rupture into the brainstem. They demonstrated rapid clinical and radiographic resolution after stabilization of cranial cervical junction only 12 weeks postsurgery.

https://thejns.org/doi/abs/10.3171/CASE21662

KEYWORDS CPPD; crystal arthropathy; odontoid pseudotumor; brainstem; calcium pyrophosphate; occiput cervical fusion

Calcium pyrophosphate dihydrate (CPPD) deposition disease (pseudogout), in which calcium pyrophosphate crystals are identified from synovial fluid aspirate, was first described in $1962 .^{1}$ CPPD may present acutely with inflammatory oligoarthritis lasting weeks to months, and typically it has a predilection for the knees and wrists. In its chronic form, it may present with polyarticular arthritis resembling osteoarthritis, with severe joint changes, intermittent inflammatory flares, and a tendency to involve glenohumeral joints, wrists, and metacarpophalangeal joints. ${ }^{2}$ A certain subtype of chronic CPPD may mimic rheumatoid arthritis, with a more persistent inflammatory arthropathy affecting small and large joints. The pathophysiology underlying CPPD involves calcium pyrophosphate crystal formation in articular cartilage, subsequent synovial inflammation, and resultant direct catabolism of joint tissues and cartilage degeneration. ${ }^{2}$
CPPD involvement in the cervical spine is a relatively uncommon entity; previous studies have demonstrated calcium pyrophosphate deposition in intervertebral disks and ligamentum flavum among affected patients. ${ }^{3,4}$ One series described 18 cases of crowded dens syndrome characterized by acute onset of febrile neck pain, elevated serum inflammatory markers, and computed tomography (CT) evidence of craniocervical ligament calcification in which calcium pyrophosphate deposition was identified in most cases. ${ }^{5}$ Craniocervical or subaxial cervical spinal CPPD has been rarely shown to cause acute neck pain, cervical myelopathy, and, in severe cases, quadriparesis. ${ }^{6-13}$ Nonsurgical therapy for cervical CPPD typically involves nonsteroidal antiinflammatory therapy or steroid therapy for acute flares and colchicine for longer term suppressive therapy. ${ }^{2,14}$ However, in the setting of acute neurological

ABBREVIATIONS CPPD = calcium pyrophosphate dihydrate; CT = computed tomography; MRI = magnetic resonance imaging INCLUDE WHEN CITING Published February 21, 2022; DOI: 10.3171/CASE21662.

SUBMITTED November 22, 2021. ACCEPTED December 7, 2021.

(C) 2022 The authors, CC BY-NC-ND 4.0 (http://creativecommons.org/licenses/by-nc-nd/4.0/). 
compromise secondary to compressive subaxial or craniocervical junction CPPD, operative intervention has been described in different reports through transoral resection of the anterior arch of $\mathrm{C} 1$ and odontoid either alone or in combination with posterior cervical decompression and fusion (Table 1).

Herein, we present for the first time a case of cervical CPPD with associated retro-odontoid pseudotumor rupture into the brainstem leading to acute cranial neuropathy, quadriparesis, and respiratory failure. We describe a technique for posterolateral CT-guided needle biopsy of a retro-odontoid cyst, followed by treatment of C1-2 CPPD through posterior occipital cervical fusion alone without ventral decompression. The clinical course along with subsequent radiographic resolution of the compressive effects are highlighted. A comprehensive literature review was performed to examine cases in which operative intervention for craniocervical and subaxial cervical CPPD was undertaken.

\section{Illustrative Case}

A 68-year-old man with a history of chronic pain, remote left hip arthroplasty, depression, and atrial fibrillation presented to the emergency department with a history of several preceding months of bilateral hand numbness and acute onset of paresthesia in both arms and legs. These symptoms were followed by diplopia, gait instability, and speech difficulty. Clinically, he was awake and alert; his pertinent physical examination findings included bilateral sixth nerve palsies, preserved vertical eye movements, dysarthria, and hoarse speech. His face was symmetric, there was normal facial sensation, and tongue protrusion was midline. His distal power was reduced in the bilateral upper extremities, with evidence of intrinsic muscle wasting, diffuse hyperreflexia, and an upward left plantar reflex. Shortly after admission, he was unable to maintain adequate oxygenation and developed quadriparesis with only antigravity strength in the myotomes of his left side. His level of consciousness declined, necessitating intubation. He was transferred to our neurosurgical center for further investigation and management.

On arrival at the neurosurgical center, he had no responses to central or peripheral pain, and his pupils remained reactive to light. CT revealed a lytic lesion at $\mathrm{C} 2$ with evidence of cortical erosion through the posterior odontoid wall (Fig. 1). Magnetic resonance imaging (MRI) demonstrated an epidural cystic structure extending superiorly into the retro-odontoid and retroclival spaces that appeared to contact the pontomedullary junction of the brainstem. The entire craniocaudal extent of the lesion was $6.7 \mathrm{~cm}$. The retroclival epidural cystic structure was in continuity with a cystic cavitation within the pons measuring $2.2 \times$ $2.2 \times 2.4 \mathrm{~cm}$, raising the possibility that the epidural lesion ruptured through the dural membrane and entered the pons. A thin border at the posterior aspect of the pontine cystic lesion separated it from the fourth ventricle. The $\mathrm{C} 2$ lesion demonstrated rim enhancement following gadolinium administration, and both the retro-odontoid and pontine regions exhibited increased susceptibility in keeping with hemorrhagic contents. Abscess was believed unlikely given complete absence of diffusion restriction. There were severe spondylotic changes between the occiput and $\mathrm{C} 2$, calcification of the apical and alar ligaments, facet degeneration between the articulations of occiput and $\mathrm{C} 1-2$, and autofusion at C2, C3, and C4. The radiographic differential diagnosis included a synovial-based process, such as calcium pyrophosphate deposition disease or pigmented villonodular synovitis, versus a chronic infection or craniocervical neoplasm, such as chordoma.
After interdisciplinary case review, CT-guided biopsy was performed by interventional neuroradiology. The patient was placed prone, and contrast-enhanced CT was performed to identify the vertebral arteries. A needle trajectory was planned to target the lytic lesion at C2 via a posterolateral approach, passing between the laminae of C2 and C3 to enter the epidural space. An 18-gauge 9$\mathrm{cm}$ spinal needle was advanced to the lateral epidural space; needle tip position was confirmed on imaging and epidural location was demonstrated through injection of a small volume of air. Next, the needle was advanced in the epidural space along the pedicle and carefully stepped along the posterior cortex of the C2 vertebral body until its tip was visualized within the lytic lesion in the dens (Fig. 2). Aspiration yielded partially coagulated chronic appearing sanguineous material. Fluid microbiology was negative for any growth, and cytology was negative for malignant cells. Microscopy confirmed positivity for intracellular birefringent crystals with rare calcium pyrophosphate crystals, thus confirming a diagnosis of retro-odontoid pseudotumor secondary to CPPD. Subsequent shoulder radiographs showed severe bilateral glenohumeral articular degenerative findings, chondrocalcinosis, and ossific bodies in the axillary recess, also in keeping with advanced CPPD arthropathy. The patient was maintained on dexamethasone therapy and over the following week demonstrated gradual improvement in neurological function. He remained intubated, his eyes opened spontaneously, and he obeyed commands in four extremities. He had 1/5 power in right-sided myotomes and $3 / 5$ power in left-sided myotomes through upper and lower extremities.

Given his significant improvement in level of consciousness with steroid therapy, definitive surgical management was discussed. A ventral decompression with odontoidectomy was believed to pose significant morbidity given the operative risks and his current clinical condition. A transsphenoidal transclival skull base approach to the brainstem was also considered although it was believed to pose high operative risk. Moreover, concerns regarding radiographic findings suggestive of a dural membrane breach were also considered in the context of the associated risk of postoperative infection and cerebrospinal fluid leak. We felt that this retro-odontoid pseudotumor was likely the result of instability at the craniocervical junction and secondary joint synovium hypertrophy and crystal deposition. With this rationale, a posterior occipital-cervical fusion would achieve the goal of restoring craniocervical junction stability and facilitating calcium pyrophosphate deposition resolution with fusion of motion segments. The patient therefore received surgery for posterior occiput-C3 instrumented fusion with occipital plate, C2 pedicle screws, and $\mathrm{C} 3$ lateral mass screws (Fig. $3 \mathrm{~A}$ and $\mathrm{B}$ ). After a period in the intensive care unit, the patient was extubated within 1 week and started on inpatient physiotherapy. At his 4-week postsurgical follow-up, the strength in his upper and lower extremities had improved substantially although he remained nonambulatory and continued to experience difficulty feeding himself. MRI performed at the 12-week follow-up examination demonstrated marked and rapid resolution of the retro-odontoid pseudotumor with no ongoing compressive myelopathy and improvement in the brainstem cystic lesion (Fig. 3C).

\section{Discussion \\ Observations}

Craniocervical junction manifestations of inflammatory arthritides remain an important diagnostic consideration for neurosurgeons. The most common radiographic presentation of craniocervical junction CPPD is as a periodontoid "pseudotumor," a partially calcified 
TABLE 1. Summary of operative management and outcome for reported craniocervical and subaxial cervical spine calcium pyrophosphate deposition disease

\begin{tabular}{|c|c|c|c|c|c|}
\hline Authors \& Year & $\begin{array}{l}\text { Patients } \\
\text { (n) }\end{array}$ & Presentation & Lesion Location & Surgical Intervention & Outcome \\
\hline $\begin{array}{l}\text { Nagashima et al., } \\
1984^{17 *}\end{array}$ & 3 & $\begin{array}{l}\text { Neck pain }(n=2) \text {, } \\
\text { paresthesias }(n=1) \text {, } \\
\text { tetraparesis }(n=1)\end{array}$ & Subaxial spine & $\begin{array}{l}\text { Laminectomy w/o fusion ( } \mathrm{n} \\
\quad=3 \text { ), additional } \\
\text { facetectomy }(\mathrm{n}=2)\end{array}$ & $\begin{array}{l}\text { Neurological improvement } \\
(\mathrm{n}=3) ; 1 \text { patient died of } \\
\text { postoperative pneumonia }\end{array}$ \\
\hline $\begin{array}{l}\text { Berghausen et al., } \\
1985^{18 *}\end{array}$ & 1 & Paresthesias, weakness, ataxia & Subaxial spine & $\begin{array}{l}\text { Laminectomy w/o fusion } \\
\text { (C2-4) }\end{array}$ & Neurological improvement \\
\hline $\begin{array}{l}\text { Kawano et al., } \\
1988^{19 *}\end{array}$ & 3 & $\begin{array}{c}\text { Paresthesias \& ataxia } \\
(\mathrm{n}=3), \text { quadriparesis }(\mathrm{n}=3)\end{array}$ & Subaxial spine & Laminectomy w/o fusion & $\begin{array}{l}\text { Neurological improvement } \\
\qquad(\mathrm{n}=3)\end{array}$ \\
\hline $\begin{array}{l}\text { Ciricillo \& Weinstein, } \\
1989^{12}\end{array}$ & 1 & $\begin{array}{l}\text { Paresthesias, weakness, } \\
\text { incoordination }\end{array}$ & $\begin{array}{c}\text { Craniocervical } \\
\text { junction }\end{array}$ & $\begin{array}{l}\text { Transoral resection of } \mathrm{C} 1 \\
\text { arch, } \mathrm{C} 2 \text { body, \& dens }\end{array}$ & Neurological improvement \\
\hline $\begin{array}{l}\text { Gomez \& Chou, } \\
1989^{20 *}\end{array}$ & 1 & Neck pain, weakness, ataxia & Subaxial spine & $\begin{array}{l}\text { Laminectomy (C3-5) w/ } \\
\text { interfacet wire fusion (C2-6) }\end{array}$ & Neurological improvement \\
\hline $\begin{array}{l}\text { Kingdom et al., } \\
1995^{28}\end{array}$ & 1 & $\mathrm{~N} / \mathrm{A}$ & $\begin{array}{l}\text { Craniocervical } \\
\text { junction (C1-2) }\end{array}$ & $\begin{array}{l}\text { Transoral } \\
\text { transpalatopharyngeal } \\
\text { resection }\end{array}$ & $N / A$ \\
\hline $\begin{array}{l}\text { Norris \& Hope, } \\
\quad 1995^{21 *}\end{array}$ & 1 & Quadriparesis & Subaxial spine & Laminectomy w/o fusion & Neurological improvement \\
\hline $\begin{array}{l}\text { Shaffrey et al., } \\
1995^{26}\end{array}$ & 1 & Neck pain & $\begin{array}{c}\text { Craniocervical } \\
\text { junction (posterior } \\
\text { C1-2) }\end{array}$ & $\begin{array}{l}\text { En bloc posterior resection } \\
\text { of lesion, } \mathrm{C} 1-3 \text { laminectomy } \\
\text { w/o fusion }\end{array}$ & Clinical improvement \\
\hline $\begin{array}{l}\text { Zünkeler et al., } \\
1996^{29}\end{array}$ & 7 & $\begin{array}{l}\text { Neck pain }(n=3) \text {, paresthesias } \\
(n=6) \text {, ataxia }(n=5) \text {, fine } \\
\text { motor problems }(n=7)\end{array}$ & $\begin{array}{l}\text { Craniocervical } \\
\text { junction }\end{array}$ & $\begin{array}{l}\text { Transoral transpharyngeal } \\
\text { resection including } C 1 \text { arch \& } \\
\text { dens }(n=7), \text { posterior } \\
\text { occiput to C2 fusion }(n=6)\end{array}$ & $\begin{array}{l}\text { Neurological improvement } \\
\qquad(\mathrm{n}=7)\end{array}$ \\
\hline $\begin{array}{l}\text { Hasegawa et al., } \\
2000^{34}\end{array}$ & 1 & $\begin{array}{l}\text { Paresthesias, ataxia, } \\
\text { incoordination }\end{array}$ & $\begin{array}{l}\text { Craniocervical } \\
\text { junction }\end{array}$ & $\begin{array}{l}\text { Posterolateral resection } \\
\text { including C1 } \\
\text { hemilaminectomy \& partial } \\
\text { C2 hemilaminecomy }\end{array}$ & Neurological improvement \\
\hline $\begin{array}{l}\text { Yamagami et al., } \\
2000^{22 *}\end{array}$ & 1 & $\begin{array}{c}\text { Hypesthesia, arm weakness, } \\
\text { ataxia }\end{array}$ & Subaxial spine & $\begin{array}{l}\text { Laminectomy (C4-6) w/o } \\
\text { fusion }\end{array}$ & Neurological improvement \\
\hline $\begin{array}{l}\text { Griesdale et al., } \\
2004^{30}\end{array}$ & 1 & Numbness, hand weakness & $\begin{array}{l}\text { Craniocervical } \\
\text { junction }\end{array}$ & $\begin{array}{l}\text { Transoral resection \& } \\
\text { posterior C1-2 fusion w/ } \\
\text { transarticular screw \& } \\
\text { interlaminar autograft }\end{array}$ & Neurological improvement \\
\hline $\begin{array}{l}\text { Muthukumar \& } \\
\text { Karuppaswamy, } \\
2003^{23 *}\end{array}$ & 2 & Quadriparesis $(n=2)$ & Subaxial spine & Laminectomy w/o fusion & Neurological improvement \\
\hline Lin et al., $2006^{33}$ & 1 & Weakness, paresthesias & $\begin{array}{l}\text { Craniocervical } \\
\text { junction (retro- } \\
\text { odontoid) \& } \\
\text { subaxial spine } \\
\text { (ligamentum } \\
\text { flavum) }\end{array}$ & $\begin{array}{l}\text { Laminectomy (C3-6) w/o } \\
\text { fusion, including removal of } \\
\text { ligamentum flavum up to } \\
\text { posterior arch of atlas }\end{array}$ & Neurological improvement \\
\hline Doita et al., $2007^{10}$ & 1 & Weakness, paresthesias & $\begin{array}{l}\text { Craniocervical } \\
\text { junction }\end{array}$ & $\begin{array}{l}\text { Posterolateral resection w/ } \\
\text { C1 laminectomy \& partial } \\
\text { C2 hemilaminectomy }\end{array}$ & Neurological improvement \\
\hline Sethi et al., $2007^{35}$ & 1 & Quadriparesis & $\begin{array}{l}\text { Craniocervical } \\
\text { junction (w/ } \\
\text { intradural } \\
\text { extension, vertebral } \\
\text { encasement) }\end{array}$ & $\begin{array}{l}\text { Posterolateral resection w/ } \\
\text { C1 \& C2 laminectomies, no } \\
\text { fusion }\end{array}$ & $\begin{array}{l}\text { Postoperative quadriplegia, } \\
\text { ventilator dependence } \\
\text { leading to death from } \\
\text { pneumonia \& sepsis }\end{array}$ \\
\hline
\end{tabular}


TABLE 1. Summary of operative management and outcome for reported craniocervical and subaxial cervical spine calcium pyrophosphate deposition disease

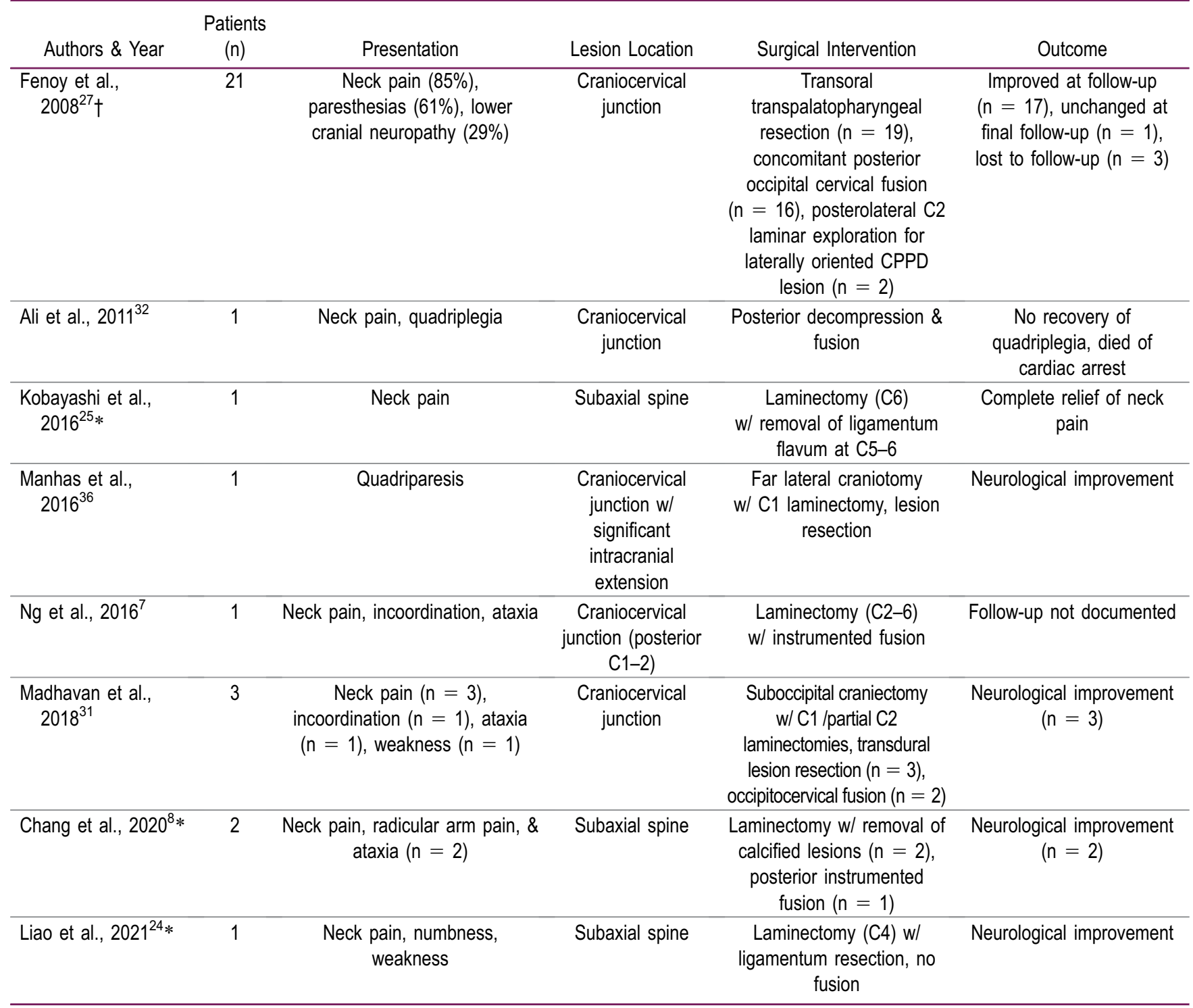

$\mathrm{N} / \mathrm{A}=$ not applicable.

* Isolated subaxial ligamentum flavum CPPD.

$\dagger$ Review article.

soft-tissue mass centered behind the odontoid process in direct contact with the transverse ligament that may compress the cervical spinal cord with progressive growth. ${ }^{15}$ Although no clear imaging features can distinguish nonrheumatoid (such as CPPD) from rheumatoid causes of periodontoid pseudotumor, the typical radiological manifestations of craniocervical junction CPPD include calcific deposits in the annulus fibrosis and transverse ligament of the dens as well as in the supraspinous, interspinous, and longitudinal ligaments of the surrounding cervical spine. ${ }^{15,16}$ CT of the cervical spine may show mineralization within the pseudotumor, which may be associated with crowded dens syndrome, although this may also be present in hydroxyapatite deposition and appear almost identical to CPPD. ${ }^{15,16} \mathrm{MRI}$ of the cervical spine usually shows low T1 signal and heterogeneous T2 signal within the pseudotumor. Associated arthropathy may also be seen, characterized by narrowing of the intervertebral discs, osteophytes, bony sclerosis, and bony erosions with subchondral cysts. ${ }^{15}$ Finally, increased motion at the craniocervical junction may often be present on flexion-extension radiographs in a manner similar to rheumatoid arthritis, with suspected shared mechanical instability pathophysiology underlying further joint space disease. ${ }^{16}$ Other differential diagnoses in this region include bony neoplasms, such as chordoma or sarcoma, chronic infectious processes, and, in our case, primary intraparenchymal brain neoplasms given the significant brainstem lesion. 

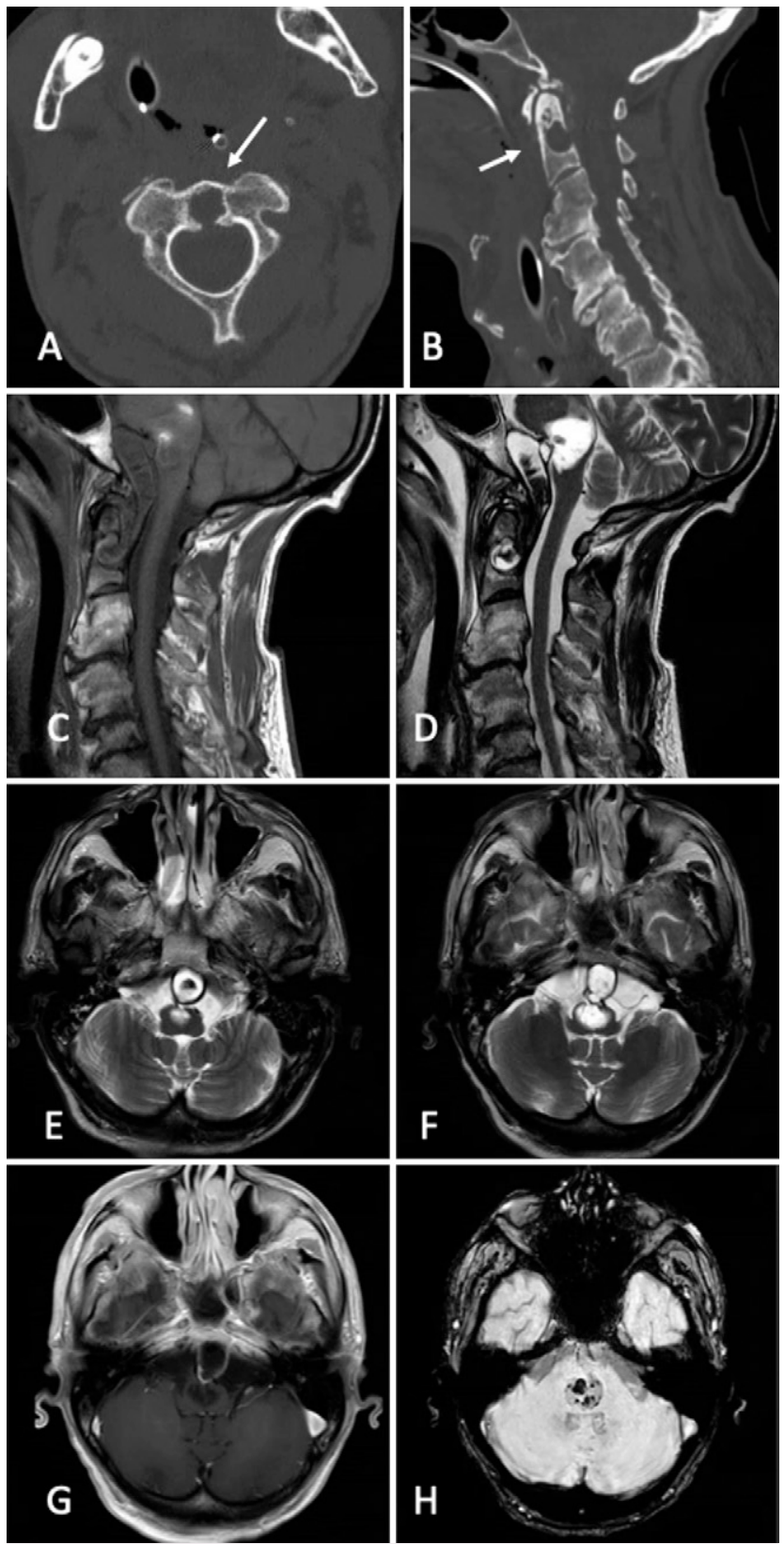

FIG. 1. A and B: CT bone window axial and sagittal images depicting Iytic $\mathrm{C} 2$ odontoid lesion (white arrows) and multilevel cervical spondylosis. Midsagittal T1- (C) and T2- (D) weighted MRI shows a primarily T1 dark, heterogeneously T2 bright lesion at $\mathrm{C} 2$ with dorsal and cranial extension in the epidural space to the level of the clivus, with a T2 hyperintense collection at the ventral pontomedullary junction containing foci of high T1 signal, suggesting subacute blood products. $E$ and F: Axial T2-weighted images at different levels in the brainstem showing apparent continuity between the retroclival epidural collection and the pontine cystic lesion. G: Axial T1-weighted gadolinium-enhanced sequence demonstrating rim enhancement (but no internal enhancement), confirming a cystic lesion. $\mathrm{H}$ : Susceptibility weighted sequence showing pontine intracystic hemorrhagic material.

The optimal surgical strategy for craniocervical and subaxial spinal CPPD is not clear. Results from our literature review on surgical management strategies and outcomes of subaxial and craniocervical junction

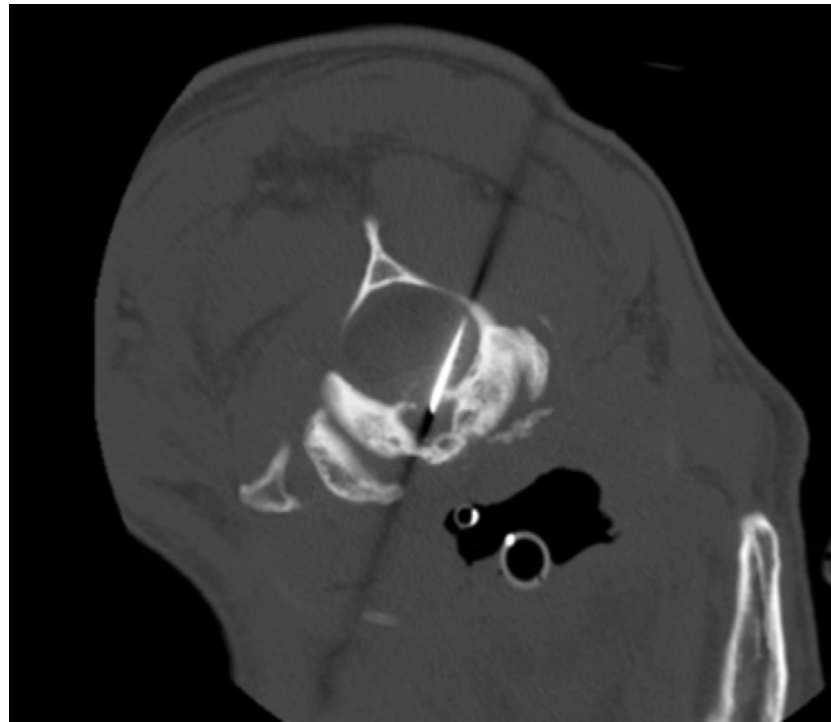

FIG. 2. CT image demonstrates the biopsy needle tip within the odontoid cystic lesion. The needle was advanced into the epidural space and then along $\mathrm{C} 2$ pedicle until it reached the odontoid lesion.

CPPD are summarized in Table 1 and included 24 articles with relevant cases. No identified cases used isolated posterior fusion for craniocervical junction CPPD, nor did any cases describe such profound retro-odontoid pseudotumor rupture into the brainstem, as in this report. Ten articles reported on CPPD in the subaxial cervical spine ( $n=16$ patients), most commonly involving the ligamentum flavum. Symptoms in this group included neck pain, radiculopathy, and myelopathy. All cases underwent focal posterior decompression, and one underwent fusion with neurological improvement, with the exception of one postoperative mortality secondary to pneumonia. ${ }^{8,17-25}$ Two articles ( $\mathrm{n}=2$ patients) reported posterior craniocervical junction involvement, and both patients were treated with posterior decompression (fusion in one case); one patient improved, and no follow-up was available for the other. ${ }^{7,26}$ The remaining articles identified described retro-odontoid CPPD pseudotumor management through different surgical techniques across a total of 40 patients. Neck pain, paresthesia, ataxia, motor weakness/quadriparesis, myelopathy, and lower cranial neuropathies were described in this subgroup. Thirty-one patients received transoral resections, and a total of 23 were stabilized with concomitant posterior fusion including either occipital cervical fusion $(\mathrm{n}=22)$ or $\mathrm{C} 1-2$ fusion $(\mathrm{n}=1) .^{12,27-30}$ No mortalities were reported in this group; most patients improved, four patients did not have follow-up information, and one patient was unchanged at follow-up. Posterior suboccipital craniectomy and $\mathrm{C} 1-2$ partial laminectomies with transdural pseudotumor resection with or without occipital cervical fusion was performed in three patients with improvement in all cases. ${ }^{31}$ Posterior craniocervical junction decompression alone for ligamentum flavum calcium deposition was performed in two patients; one had neurological improvement and the other passed away secondary to cardiac arrest. $^{32,33}$ Four patients received posterolateral resection (C1-2 laminectomies), with posterior fusion in one case. ${ }^{10,27,34}$ Of this group, there was improvement in two cases, and none worsened postoperatively. This excluded the two patients with significant intracranial extension. Two patients had significant intracranial extension most similar to our case. Both were treated with posterolateral resection without fusion, and one patient had postoperative quadriplegia and ventilator dependence and 


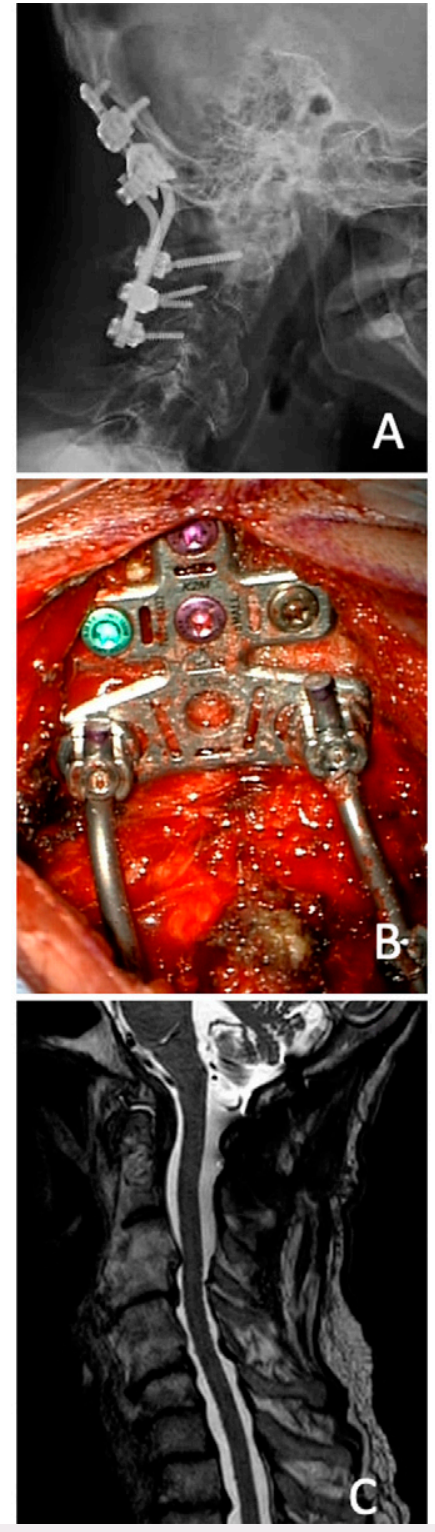

FIG. 3. A: Postoperative lateral upright radiograph demonstrates a stable occipital cervical construct with appropriate occipital plate, $\mathrm{C} 2$ pedicle screw, and C3 lateral mass screw hardware position. B: Intraoperative image depicting occipital plate component of occipital-cervical fusion construct. C: Midsagittal T2-weighted MRI demonstrating improvement in compressive retro-odontoid and retroclival pseudotumor and cystic brainstem lesion.

died due to respiratory sepsis whereas the other experienced neurological improvement. ${ }^{35,36}$ Nonsurgical management for degenerative retroodontoid pseudotumor has also been described using rigid cervical collar immobilization with good clinical and radiographic results although this strategy certainly requires close surveillance and may be considered in patients with high operative risk or significant frailty. ${ }^{37}$

\section{Lessons}

It is challenging to generate overall surgical management recommendations given the heterogeneity of included case imaging and patient features. A broad differential diagnosis, including inflammatory arthritides, should be considered with high cervical lesions. When possible, efforts should be made to confirm diagnoses with a direct biopsy if imaging is not clear to determine optimal next-management strategies. We demonstrate for the first time an instance of complete resolution of craniocervical junction compressive myelopathy secondary to retro-odontoid and retroclival CPPD with posterior occipital cervical fusion alone. This approach may be considered when a patient's clinical circumstances suggest that the morbidity profile of a ventral approach is unfavorable. Furthermore, we provide a summary of management strategies used in available literature that demonstrate good efficacy and result in improvement in neurological status in most cases of CPPD. Overall limitations include lack of long-term follow-up in available literature, especially when comparing long-term craniocervical junction stability in cases receiving fusion versus no fusion. This remains an area to be addressed in future studies.

\section{References}

1. McCarty D Jr, Kohn NN, Faires JS. The significance of calcium pyrophosphate crystals in the synovial fluid of arthritic patients: the "pseudogut syndrome." Clinical aspects. Ann Intern Med. 1962;56:711-737.

2. Rosenthal AK, Ryan LM. Calcium pyrophosphate deposition disease. N Engl J Med. 2016;374(26):2575-2584.

3. Lee RS, Kayser MV, Ali SY. Calcium phosphate microcrystal deposition in the human intervertebral disc. J Anat. 2006;208(1):13-19.

4. Yayama T, Kobayashi S, Sato R, et al. Calcium pyrophosphate crystal deposition in the ligamentum flavum of degenerated lumbar spine: histopathological and immunohistological findings. Clin Rheumatol. 2008;27(5):597-604.

5. Godfrin-Valnet M, Godfrin G, Godard J, et al. Eighteen cases of crowned dens syndrome: presentation and diagnosis. Neurochirurgie. 2013;59(3):115-120.

6. Sekijima Y, Yoshida T, Ikeda S. CPPD crystal deposition disease of the cervical spine: a common cause of acute neck pain encountered in the neurology department. J Neurol Sci. 2010;296(1-2):79-82.

7. Ng IB, Arkun K, Riesenburger RI. Posterior C1-C2 calcium pyrophosphate dihydrate crystal deposition disease. BMJ Case Rep. 2016;2016:bcr2016214771.

8. Chang DG, Park JB, Jung HY, Seo KJ. Cervical myelopathy due to subaxial calcium pyrophosphate dihydrate (CPPD) deposition with simultaneous asymptomatic crowned dens syndrome: two case reports. BMC Musculoskelet Disord. 2020;21(1):713.

9. Fye KH, Weinstein PR, Donald F. Compressive cervical myelopathy due to calcium pyrophosphate dihydrate deposition disease: report of a case and review of the literature. Arch Intern Med. 1999; 159(2):189-193.

10. Doita M, Shimomura T, Maeno K, Nishida K, Fujioka H, Kurosaka M. Calcium pyrophosphate dihydrate deposition in the transverse ligament of the atlas: an unusual cause of cervical myelopathy. Skeletal Radiol. 2007;36(7):699-702.

11. Turaga S, Thomas M, Savy L, Schreiber BE. Pseudogout or pseudolymphoma? Calcium pyrophosphate deposition disease of the cervical spine: a rare presentation and literature review. BMJ Case Rep. 2019;12(12):e231508.

12. Ciricillo SF, Weinstein PR. Foramen magnum syndrome from pseudogout of the atlanto-occipital ligament. Case report. J Neurosurg. 1989;71(1):141-143.

13. Wells CR, Morgello S, DiCarlo E. Cervical myelopathy due to calcium pyrophosphate dihydrate deposition disease. J Neurol Neurosurg Psychiatry. 1991;54(7):658-659.

14. Iqbal SM, Qadir S, Aslam HM, Qadir MA. Updated treatment for calcium pyrophosphate deposition disease: an insight. Cureus. 2019;11(1):e3840. 
15. Shi J, Ermann J, Weissman BN, Smith SE, Mandell JC. Thinking beyond pannus: a review of retro-odontoid pseudotumor due to rheumatoid and non-rheumatoid etiologies. Skeletal Radiol. 2019;48(10):1511-1523.

16. Chang EY, Lim WY, Wolfson T, et al. Frequency of atlantoaxial calcium pyrophosphate dihydrate deposition at CT. Radiology. 2013;269(2):519-524.

17. Nagashima C, Takahama M, Shibata T, et al. Calcium pyrophosphate dihydrate deposits in the cervical ligamenta flava causing myeloradiculopathy. J Neurosurg. 1984;60(1):69-80.

18. Berghausen E, Balogh K, Landis W, Lee D, Wright A. Cervical myelopathy attributable to pseudogout. Clin Orthop. 1987;214:217-221.

19. Kawano N, Matsuno T, Miyazawa S, et al. Calcium pyrophosphate dihydrate crystal deposition disease in the cervical ligamentum flavum. J Neurosurg. 1988;68(4):613-620.

20. Gomez H, Chou SM. Myeloradiculopathy secondary to pseudogout in the cervical ligamentum flavum: case report. Neurosurgery. 1989;25(2):298-302.

21. Norris JS, Hope DT. Cervical myelopathy caused by pseudogout. Br J Neurosurg. 1995;9(1):103-105.

22. Yamagami T, Kawano N, Nakano H. Calcification of the cervical ligamentum flavum: case report. Neurol Med Chir (Tokyo). 2000; 40(4):234-238.

23. Muthukumar N, Karuppaswamy U. Tumoral calcium pyrophosphate dihydrate deposition disease of the ligamentum flavum. Neurosurgery. 2003;53(1):103-109.

24. Liao JH, Huang KC, Hsieh CT, Sun JM. Cervical myeloradiculopathy as an initial presentation of pseudogout. Neurosciences (Riyadh). 2021;26(1):93-96.

25. Kobayashi T, Miyakoshi N, Abe T, et al. Acute neck pain caused by pseudogout attack of calcified cervical yellow ligament: a case report. J Med Case Reports. 2016;10(1):133.

26. Shaffrey $\mathrm{Cl}$, Munoz EL, Sutton CL, Alston SR, Shaffrey ME, Laws ER Jr. Tumoral calcium pyrophosphate dihydrate deposition disease mimicking a cervical spine neoplasm: case report. Neurosurgery. 1995;37(2):335-339.

27. Fenoy AJ, Menezes AH, Donovan KA, Kralik SF. Calcium pyrophosphate dihydrate crystal deposition in the craniovertebral junction. J Neurosurg Spine. 2008;8(1):22-29.

28. Kingdom TT, Nockels RP, Kaplan MJ. Transoral-transpharyngeal approach to the craniocervical junction. Otolaryngol Head Neck Surg. 1995;113(4):393-400.

29. Zünkeler B, Schelper R, Menezes AH. Periodontoid calcium pyrophosphate dihydrate deposition disease: "pseudogout" mass lesions of the craniocervical junction. J Neurosurg. 1996;85(5):803-809.

30. Griesdale DEG Jr, Boyd M, Sahjpaul RL. Pseudogout of the transverse atlantal ligament: an unusual cause of cervical myelopathy. Can J Neurol Sci. 2004;31(2):273-275.
31. Madhavan K, Chieng LO, Gaynor BG, Levi AD. Transdural approach to resection of retro-odontoid cysts in elderly patients: report of 3 cases. J Neurosurg Spine. 2018;28(3):236-243.

32. Ali S, Hoch M, Dadhania V, Khurana JS. CPPD crowned dens syndrome with clivus destruction: a case report. J Radiol Case Rep. 2011;5:30-37.

33. Lin SH, Hsieh ET, Wu TY, Chang CW. Cervical myelopathy induced by pseudogout in ligamentum flavum and retro-odontoid mass: a case report. Spinal Cord. 2006;44(11):692-694.

34. Hasegawa H, Nakajima Y, Mabuchi E, Hashiba T, Miyao Y. Retroodontoid massive calcium pyrophosphate crystal deposition: case report. Neurol Med Chir (Tokyo). 2000;40(7):387-390.

35. Sethi KS, Garg A, Sharma MC, Ahmad FU, Sharma BS. Cervicomedullary compression secondary to massive calcium pyrophosphate crystal deposition in the atlantoaxial joint with intradural extension and vertebral artery encasement. Surg Neurol. 2007; 67(2):200-203.

36. Manhas A, Kelkar P, Keen J, Rostad S, Delashaw JB. Recurrent craniocervical pseudogout: indications for surgical resection, surveillance imaging, and craniocervical fixation. Cureus. 2016;8(2):e511.

37. Klas PG, Wilson J, Cusimano MD. Regression of degenerative retro-odontoid pseudotumour treated in a collar. Can J Neurol Sci. 2018;45(5):599-600.

\section{Disclosures}

The authors report no conflict of interest concerning the materials or methods used in this study or the findings specified in this paper.

\section{Author Contributions}

Conception and design: AK Malhotra, Balachandar, Guest, Witiw. Acquisition of data: all authors. Analysis and interpretation of data: AK Malhotra, AR Malhotra, Balachandar, Bharatha, Marotta. Drafting the article: AK Malhotra, AR Malhotra, Landry, Balachandar. Critically revising the article: AR Malhotra, Landry, Balachandar, Guest, Witiw. Reviewed submitted version of manuscript: AR Malhotra, Landry, Guest, Bharatha, Marotta, Witiw. Approved the final version of the manuscript on behalf of all authors: AK Malhotra. Administrative/ technical/material support: Bharatha, Marotta, Witiw. Study supervision: Witiw.

\section{Correspondence}

Armaan K. Malhotra: St. Michael's Hospital, Toronto, ON, Canada. ak. malhotra@mail.utoronto.ca. 